\title{
The Fight Against Enzy US Libraries During the Influenza Epidemic of 1918
}

\author{
Lorri Mon
}

In 2020, a pandemic of the COVID-19 novel coronavirus struck worldwide, rapidly becoming the most devastating since the 1918 global influenza pandemic. As librarians confronted entirely new challenges in how to safely manage libraries during the COVID-19 crisis, a common question was, "what happened in libraries during the 1918 influenza pandemic?" This article explores that question through the lens of government documents and news articles of the 1918-1921 time period, seeking to understand what happened then in libraries nationwide, and what we might learn from it today.

\section{$\boldsymbol{4}$} hief River Falls and Moorhead Hit by 'Enzy,'” a news article in the Duluth News Tribune in Duluth, Minnesota announced on October 10, 1918. ${ }^{1}$ With 150 cases of influenza and two deaths reported locally, the board of health stepped in to close the public library as well as all public schools, theaters and churches. For many libraries nationwide, October 1918 was the first crisis point in the influenza epidemic. A wave of closures nationwide included libraries in Asheville, North Carolina (October 5); Olympia, Washington (October 7); Tulsa, Oklahoma, Pueblo, Colorado, and Lexington, Kentucky (October 8); Grand Forks, North Dakota, Redwood City, California and Belleville, Illinois (October 10); Los Gatos, California (October 11); Fort Wayne, Indiana, Mountain View, California and Berryessa, California (October 12); Albany, Oregon (October 17); and San Francisco, California (October 18). ${ }^{2}$

The influenza epidemic of 1918 first hit the United States in March 1918 at Camp Funston in Fort Riley, Kansas. ${ }^{3}$ A year earlier, the United States had entered World War I with declarations of war against Germany and Austria-Hungary following President Woodrow Wilson's speech to a joint session of Congress on April 2, 1917. ${ }^{4}$ The 1918 pandemic's first wave in the US thus hit young men crowded into barracks in World War I training camps, and spread onward to local civilians. Testifying at a September 28, 1918 US Senate hearing, US Surgeon General Rupert Blue reported, "35 States have been invaded by the disease," specifically naming Alabama, Arkansas, California, Colorado, Connecticut, Delaware, Florida, Georgia, Illinois, Indiana, Kansas, Kentucky, Louisiana, Maine, Maryland, Massachusetts, Michigan, Minnesota, Mississippi, Missouri, Montana, New Hampshire, New Jersey, New Mexico, New York, North Carolina, Pennsylvania, Rhode Island, South Carolina, South Dakota, Texas, Vermont, Virginia, Washington, and West Virginia, and also describing an "epidemic" level of influenza outbreak in localities including Florence, Alabama; Lonoke County in Arkansas; Key West, Florida; Portland, Maine; Portsmouth, New Hampshire; Raleigh and Wilmington, North Carolina; and Portsmouth and Norfolk, Virginia. ${ }^{5}$ At Boston, Massachusetts, the Surgeon General reported 618 deaths from influenza and 197 deaths from pneumonia occurring within just the ten-day period of September 16 to September $26,2018 .^{6}$

The hearing also included an article from the Department of the Navy's Bureau of Medicine and Surgery, describing how the disease progressed with onset of chills, severe headache, and body aches, or at times beginning with nausea, vomiting and abdominal pain, and an early onset of fever, frequently with a later onset of "a bad cold in the head with raw throat and dry cough." 7 Testifying about his experience in the US Navy Medical Corps, Lt. Commander J. R. Phelps noted that the influenza peaked from the eighth to the twelfth day, after which reporting of pneumonia occurred, followed by deaths coming in and increasing from the fifteenth to the twentieth days, with a forty day cycle overall. ${ }^{8}$

\section{Closing the Libraries}

Many communities around the country already knew about the influenza outbreak before it reached their own areas. For example, in Palm Beach, Florida, on September 27, 1918, the local newspaper reported on 6,139 new cases of influenza and 723 new cases of pneumonia in the military deployment camps, 
with 170 deaths, as well as 50,000 cases of Spanish influenza in Massachusetts, noting also that all theatres and places of amusement had been closed.' As the pandemic began to hit local communities, state and local boards of health often issued the orders to close places of public assembly including libraries, schools and churches, although in some cases local officials, such as the city mayor in consultation with the library board, issued closure orders. ${ }^{10}$

One of the immediate management issues for libraries was what to do about books already checked out, especially any books coming due for return while the library was closed. Many libraries dealt with this by extending due dates and/or eliminating fines. For example, in Grand Forks, North Dakota, all who had checked books out were invited to keep them until the quarantine was lifted, being assured by the librarian that "no fines for overtime will be collected." ${ }^{11}$ In other places such as Pueblo, Colorado, a recall of all library books was issued, with those who had checked out books before the quarantine being asked to return them. ${ }^{12}$ At some libraries, the librarians continued to work during the period of closure to the public. In Superior, Wisconsin, librarians worked on repairing books and taking inventory during the quarantine shutdown. ${ }^{13}$ However, in all working scenarios-whether libraries continued to have staff on site, or held temporary open hours for the recall of all books before closing down, or completely closed down until the quarantine was officially lifted-library staff eventually faced a problem of what to do about returned books which may have come from a household afflicted with influenza.

In Tulsa, Oklahoma and Olympia, Washington, janitors were in charge of fumigating both the library building and any returned library books. ${ }^{14}$ Fumigants in use at the time included sulphur and formaldehyde. ${ }^{15}$ Tulsa's library held special open hours from 9 a.m. to 12 noon for the janitor to accept book returns, explaining to the public that the request for returning all books at once in response to the quarantine order was "in order that all germs may be exterminated" since "disease has been known to be transmitted" by books. ${ }^{16}$ Superior, Wisconsin's library workers who continued working through the shutdown placed returned books coming in from homes known to have had influenza on a separate shelf to be "thoroughly fumigated." ${ }^{17}$ In Boise, Idaho, where the public library reopened on November 25, 1918 after a 30-day quarantine shutdown, those returning books were asked to report whether the books were coming from a household with influenza, and if so, those books were sent to the city fumigator along with books returned from hospitals. ${ }^{18}$ In Duluth, Minnesota, after reopening, those who returned library books from a household with influenza were asked to wrap the book in paper first, and write clearly on the outside of the package the name of the person who checked the book out. ${ }^{19}$

\section{Other Closure Issues}

Because closing down libraries, churches, schools and other public gathering places had also removed many important ways that informational materials were distributed to the public, officials needed new ways to disseminate information about influenza safety measures to people as they quarantined in their homes. The Department of the Navy's Circular 1 with brief and clear advice about influenza (e.g., "Cover the mouth with a handkerchief. Boil your handkerchiefs and other contaminated articles. Wash your hands frequently. Keep away from others as much as possible while you have a cough," etc.) which the Surgeon General had mentioned in his Congressional testimony on September 28, 1918, was one of the key informational materials printed for public distribution. ${ }^{20}$ In Montgomery, Alabama, local boys and girls were asked to volunteer to help the Public Health Service distribute pamphlets about influenza, and in Kansas City, Missouri, the Boy Scouts were requisitioned to distribute educational literature on influenza to every home, and to post flyers in public places. ${ }^{21}$ In Fargo, North Dakota, which was reporting 2,000 cases of influenza by October 10, 1918, many downtown area businesses began requiring employees to wear masks. ${ }^{22}$

Many libraries shuttered by influenza quarantines during October 1918 reopened again in November 1918, such as libraries in Tampa, Florida, Boise, Idaho, and Olympia, Washington, but some did not reopen until December 1918; for example, the public library in Virginia, Minnesota was closed for eight weeks until December 13, 1918, while Butte, Montana's public library only reopened on December 19, 1918. ${ }^{23}$ However, public libraries nationwide would unfortunately continue to experience closings and reopenings during local resurgences of the influenza epidemic over the next three years, from 1918 to 1920. In Virginia, Minnesota, the public library that had already been closed for eight weeks into mid-December 1918 was shut down again due to influenza during the first two weeks of February $1919 .^{24}$ The ongoing influenza pandemic also caused some libraries to modify their service models in ways that reduced public access to parts of the building, thus essentially enforcing what the librarians of the 2020 COVID-19 pandemic would later refer to as social distancing. In December 1918 the Butte, Montana public library upon reopening instituted a new policy of closed stacks for non-fiction, leaving only fiction books open for public browsing while all other books were accessed by request only. ${ }^{25}$ In February 1920, the Colorado Springs public library stayed open during an influenza quarantine but only by 
closing their public reading rooms and requiring people to pick up or drop off books and leave immediately, with no loitering or congregating in groups allowed-similar to what librarians of 2020 would describe as curbside pickup. ${ }^{26}$

\section{The War Effort and the Red Cross}

Libraries at this time already had been serving as partners in a war effort spearheaded by the American Library Association and the YMCA to support military training camps with books and reading materials. ${ }^{27}$ The librarian for the Indianapolis Public Library, Charles E. Rush, was on a leave of absence in November 1918 serving as assistant to the director of information of the Library War Fund, which raised money to build libraries in the camps, and library war service efforts were based at the Library of Congress in Washington, DC, under the leadership of Librarian of Congress Herbert Putnam. ${ }^{28}$ Local libraries and librarians nationwide participated both in fundraising activities for the money needed to build the camp library buildings and furnish them with shelves and seating, and also participated in coordinating a campaign of collecting book donations for camp libraries which brought in over 3 million books, although influenza quarantine shutdowns of public libraries sometimes interfered with planned local fundraising events. ${ }^{29}$ Library association meetings meanwhile were also sometimes shut down by pandemic outbreak quarantines, as happened when the Missouri Library Association and the North Dakota Library Association could not meet in October 1918, and the Montana Library Association could not meet in November $1918 .^{30}$

Libraries joined forces with the Red Cross in local efforts to combat the influenza pandemic. Two public libraries in Duluth, Minnesota, and the Butte Public Library in Montana were among those opening Red Cross rooms for the public within the library. ${ }^{31}$ Red Cross rooms were used for organizing distribution to the public of US Public Health Service literature on prevention and treatment of influenza, as well as for volunteer activities in sewing masks, bandages, and clothing to supply the troops. ${ }^{32}$ In Canadian, Texas, the Red Cross took over the library building entirely in December 1918, converting it into a temporary hospital with a capacity for housing thirty influenza patients at a time, and when in 1919 the Red Cross launched efforts to open a library in its own Minneapolis headquarters, local public libraries in the Twin Cities and the local university library offered their help. ${ }^{33}$

\section{The End of the Battle}

By the end of the pandemic, 50 million people were estimated to have died from influenza worldwide. ${ }^{34}$ Total numbers for US deaths from the influenza pandemic are difficult to determine as they were complicated by the extended timeframe and by war deaths and other pulmonary-related diseases such as tuberculosis. Influenza surveys conducted by the US Public Health Service from November 20, 1918 to February 21, 1919 surveyed 146,203 people in 12 US cities and township areas asking specifically if they or family members had been sick with influenza, pneumonia, or an illness they suspected to be influenza. There were 42,920 reported cases and 730 reported deaths, with one out of every three or four persons canvassed reporting influenza cases during this sampling period. ${ }^{35}$ Data from hospital admissions of US-based Army troops for a similar timeframe showed 434,074 total admissions for influenza, bronchitis, bronchopneumonia, and lobar pneumonia during September-December 1918, and worldwide during September-November 1918 it was estimated that $20 \%$ to $40 \%$ of US Army and Navy personnel had fallen ill with either influenza or pneumonia. ${ }^{36}$

Outbreaks of the disease continued in 1919 and 1920, and so too did the war effort supporting US troops-although World War I had officially ended with Armistice Day on November 11, 1918, it took longer to demobilize and return troops from the military camps in the United States and worldwide. In January 1920, one of the deaths noted was Miss Edith Morgan, a former student of the University of Illinois Library School, who died in the influenza epidemic while involved in work supporting the war effort in Washington, DC. ${ }^{37}$

With the shifting away from war efforts to peacetime work, the American Library Association held a regional meeting in March 15-16, 1920 in Charleston, South Carolina with librarians attending from North and South Carolina, Florida, Georgia and Virginia to discuss the launch of a new effort, "Books for Everybody." ${ }^{38}$ This new effort shifted library resources, including books being returned from the demobilized camps, to supporting an estimated 60,000,000 people throughout the US who lacked access to free public libraries, accounting for more than $75 \%$ of the total US population. ${ }^{39}$ This new plan would promote county libraries to increase local access, particularly in rural areas. ${ }^{40}$ One effort using surplus books from camp libraries undertaken immediately after this meeting was announced on March 20, 1920 by Tampa, Florida’s public library, which launched a service of supplying and exchanging books for crews of merchant ships. ${ }^{41}$ Books returned at the end of the war, which were estimated by October 1919 to be as many as 600,000 of the 2,500,000 books sent overseas which were returned in good condition, also would be offered to army post libraries for their permanent collections. ${ }^{42}$ As efforts shifted to a peacetime focus, this closed the chapter on the fight of libraries to support the 
country during the influenza epidemic in the United States and overseas.

\section{Summary}

As seen through the lens of government documents and contemporary newspaper accounts, the experience of libraries during the pandemic of 1918 bears striking similarities to the COVID-19 pandemic of 2020. Libraries in 1918 faced quarantine closures which forced difficult decisions as to whether staff would work through the shutdown or stay at home, and also problems of how to handle contaminated materials, as well as limiting public access to buildings in response to orders from public health authorities. It is particularly instructive that the 1918 pandemic took years to resolve, with libraries still facing quarantine shutdowns into 1920. Most notably, this analysis suggests the importance of maintaining institutional memory of how libraries managed during the pandemic situation. Although a significant time may pass between worldwide pandemics, libraries as memory institutions should be prepared for similar crises in future.

Lorri Mon (Imon@fsu.edu), Associate Professor, Florida State University, School of Information

\section{Notes}

1. "Thief River Falls and Moorhead hit by 'Enzy," Duluth News Tribune 153 (50), October 10, 1918, 5.

2. "Averting an Epidemic," The Asheville Citizen, October 5, 1918, 4; "Close Movies, Schools, Pool Halls in City," Olympia Daily Recorder, October 7, 1918, 1; "Many Victims of Influenza Here," Tulsa Daily World 15 (14), October 8, 1918, 1; "Library Closed During Influenza Epidemic," Tulsa Daily World 16 (14), October 9, 1918, 6; "May Return Books to Public Library," Pueblo Chieftain, October 8, 1918, 3; "State Health Board Issues Sweeping Closing Order in Fight on Spanish Plague," The Lexington Herald 281, October 8, 1918, 1; "Health Officer Says Over Twenty Cases of Influenza Exist Here," Grand Forks Daily Herald 298 (37), Grand Forks, ND, October 10, 1918, 8; "Redwood Police Chief a Victim of Influenza," San Jose Mercury Herald 95 (105), October 13, 1918, 12; "Influenza Not to Be Serious Here, It is Thought Today," Belleville News-Democrat 63 (240), Belleville, Illinois, October 10, 1918, 1; "Los Gatos Board of Health Takes Action," San Jose Mercury Herald 95 (113), October 21, 1918, 3; "Closing Order Now in Effect," The Fort
Wayne News and Sentinel 85 (244), October 12, 1918, 1; "Influenza Breaks Out at Mountain View," San Jose Mercury Herald 95 (105), October 13, 1918, 13; "Influenza Causes Library to Close," San Jose Mercury Herald 95 (106), October 13, 1918, 10; "Albany is Closed Town," Morning Oregonian 58 (18066), October 17, 1918, 6; "Libraries Closed, S.F.," The Evening News 168 (534), San Jose, California, October 19, 1918, 6.

3. Centers for Disease Control and Prevention, "Influenza (Flu): 1918 Pandemic Timeline," https://www.cdc.gov /flu/pandemic-resources/1918-commemoration/pandem ic-timeline-1918.htm.

4. "Joint Resolution Declaring That a State of War Exists Between the Imperial German Government and the Government and the people of the United States and making provision to prosecute same," 65th Congress, 1st Session, S.J. Res. 1, p.1. (April 2, 1917); "Joint Resolution Declaring That a State of War Exists Between the Imperial and Royal Austro-Hungarian Government and the people of the United States and making provision to prosecute same," 65th Congress, 2nd Session, H.J. Res. 169, (December 7, 1917).

5. "Suppression of Spanish Influenza: Hearing on H.J. Resolution 333, A Joint Resolution to Aid in Combating the Disease Known as Spanish Influenza," United States Senate Subcommittee of the Committee on Appropriations, 65th Congress, 2nd Session (September 28, 1918), 5-6.

6. "Suppression of Spanish Influenza," 6.

7. "Suppression of Spanish Influenza," 13, from "Influenza," Department of the Navy, Bureau of Medicine and Surgery, Division of Sanitation, Circular No 1., Washington, DC (September 26, 1918).

8. "Suppression of Spanish Influenza," 15.

9. "Fifty Thousand Cases of Spanish influenza in Massachusetts," The Palm Beach Post, September 27, 1918, 3.

10. "State Health Board Issues Sweeping Closing Order in Fight on Spanish Plague," The Lexington Herald, 281, October 8, 1918, 1; "Albany is Closed Town," Morning Oregonian, , 58 (18066), October 17, 1918, 6; and "Library Closed During Influenza Epidemic," Tulsa Daily World, 16 (14), October 9, 1918, 6.

11. "Health Officer Says Over Twenty Cases of Influenza Exist Here," Grand Forks Daily Herald 298 (37), Grand Forks, ND, October 10, 1918, 8.

12. "May Return Books to Public Library," Pueblo Chieftain, October 8, 1918, 3; also "City Briefs," Pueblo Chieftain, October 14, 1918.

13. "Library Takes Precaution to Prevent Influenza," Duluth News Tribune 50 (170), October 28, 1918, 4. 
14. "Library Closed During Influenza Epidemic," Tulsa Daily World 16 (14), October 9, 1918, 6; also "Close Movies, Schools, Pool Halls in City," Olympia Daily Recorder 18 (129), October 7, 1918, 1.

15. Tennessee State Library and Archives, "Disasters in Tennessee: Epidemic Scourges in Tennessee," RG 1, Department of Public Health Records, Kinyoun-Francis Sulphur Fumigator, 1917, http://sharetngov.tnsosfiles .com.s3.amazonaws.com/tsla/exhibits/disasters/images lepidemics/SulphurFumigator.jpg; also The Saturday Evening Post, B\&B Formaldehyde Fumigator, April 20, 1918, https://www.saturdayeveningpost.com/wp-content /uploads/satevepost/1918_04_20-064_SP-large.jpg; and "Six More Dead from Influenza," Tulsa Daily World, 14 (16), October 9, 1918, 1.

16. "Library Closed During Influenza Epidemic," Tulsa Daily World 16 (14), October 9, 1918, 6.

17. "Library Takes Precaution to Prevent Influenza," Duluth News Tribune 50 (170), October 28, 1918, 4.

18. "Ban Lifted on Some Boise Institutions," Idaho Daily Stateman 105, November 25, 1918, 5; also, "Fumigate Loaned Books," Idaho Daily Stateman, 107, November 27, 1918, 2.

19. "Influenza Ban Lifted: Library Will Open," Duluth News Tribune 50 (186), November 13, 1918, 4.

20. "Suppression of Spanish Influenza: Hearing on H.J. Resolution 333, A Joint Resolution to Aid in Combating the Disease Known as Spanish Influenza," United States Senate Subcommittee of the Committee on Appropriations, 65th Congress, 2nd Session (September 28, 1918), from "Influenza," Department of the Navy, Bureau of Medicine and Surgery, Division of Sanitation, Circular No 1., Washington, DC (September 26, 1918), 12-13.

21. "Fighting Influenza-Free Pamphlets on Prevention of 'Flu," The Montgomery Advertiser, October 14, 1918; and "Big Hall a Hospital," The Kansas City Star 39 (21), October 8, 1918, 2.

22. "Health Officer Says Over Twenty Cases of Influenza Exist Here," Grand Forks Daily Herald 298 (37), Grand Forks, ND, October 10, 1918, 8.

23. "Library Will Open Today After Being Closed Recently," The Tampa Morning Tribune, November 11, 1918, 7; "Ban Lifted on Some Boise Institutions," Idaho Daily Stateman 105, November 25, 1918, 5; "Library Has Reopened," Morning Olympian 27 (205), November 15, 1918, 4; "Virginia Lifts Ban at Last; Churches, Library and Theaters to Open," Duluth News Tribune 50 (217), December 14,
1918, 4; and, "Public Library Opens for Business Today," The Anaconda Standard 30 (107), December 19, 1918, 8.

24. "Will Resume Story Hours at the Virginia Library," Duluth News Tribune 50 (278), February 14, 1919, 5.

25. "Public Library Opens for Business Today," The Anaconda Standard 30 (107), December 19, 1918, 8.

26. "Library to be Open During Closing Ban; Announce Regulations," The Colorado Springs Gazette, February 10, 1920, 5.

27. "Books for Soldiers Supplied by A.L.A.," The Fort Myers Daily Press, Fort Myers FL, November 6, 1918, 6.

28. Grace Julian Clarke, "Libraries' War Work Indorsed by Club Women: Members Looking Forward to Annual Meeting," Indianapolis Star, November 10, 1918, 33; Theodore Wesley Koch, "War Libraries and Allied Studies" (New York: G. E. Stetchert and Company, 1918), 8.

29. Koch, "War Libraries and Allied Studies," 6; "Wounded Soldiers Crave Good Books," New York Times, December 29, 1918, 45; "South Boise Obeys," Idaho Stateman, October 10, 1918.

30. "Library Meet Next Month," Kansas City Star 30 (30), September 3, 1919, 1; "Library Meeting Postponed on Account of Influenza," Grand Forks Daily Herald 37 (298), October 10, 1918, 3; "Postpone Library Campaign in City," Daily Press, Newport News, Virginia, February 3, 1920; and "Library Meeting Program Issued," The Anaconda Standard, 31 (74), November 16, 1919, 11.

31. "Peace Report Makes Worker to Slip COG; Red Cross Rooms in the Lincoln Library Remain Open," Duluth News Tribune 50 (183), November 10, 1918, 6; also "More Fiction is Read by Butte Youngsters," The Anaconda Standard 30 (245), May 6, 1919, 3.

32. Gordon Williams, "When the Spanish Flu hit Seattle 100 Years Ago, the Red Cross was there," American Red Cross Northwest Region, October 5, 2018, https://red crossnw.org/2018/10/05/when-the-spanish-flu-hit-seat tle-100-years-ago-the-red-cross-was-there/; "Vignette: Flu Epidemic," December 25, 2015, Mill Valley Historical Society, https://www.mvhistory.org/vignette-flu-epidemic/; and Jessie Kratz, (2020) "Wear a Mask and Save Your Life: the 1918 Flu Pandemic," NationalArchives, April 15, 2020, https://prologue.blogs.archives.gov/2020/04/15/wear -a-mask-and-save-your-life-the-1918-flu-pandemic/.

33. "Canadian Red Cross Takes Over Library as Hospital During Influenza Epidemic," Fort Worth Star-Telegram, 38 (326), December 29, 1918, 5; April Dillon, "Hemphill County Library: About Us," October 31, 2012, https:// 
harringtonlc.org/canadian/sample-page/; "Red Cross to Open Library," Duluth News Tribune 51 (161), October 12, 1919, 12.

34. National Archives and Records Association, "The Deadly Virus: The Influenza Epidemic of 1918," https://www.ar chives.gov/exhibits/influenza-epidemic/.

35. Rollo Britten, "The Incidence of Epidemic Influenza, 1918-19*: A Further Analysis According to Age, Sex, and Color of the Records of Morbidity and Mortality Obtained in Surveys of 12 Localities," Public Health Reports 47, no. 6 (February 5, 1932): 304-10.

36. Britten, "The Incidence of Epidemic Influenza, 191819*, 309-10; Carol R. Byerly, "The U.S. Military and the Influenza Pandemic of 1918-1919," Public Health Reports 125, Suppl 3 (2010), 82.

37. Illinois Libraries (January 1920), 27.
38. Regional Meeting of Library Association," Tampa Morning Tribune, March 13, 1920, 9; also "Will Press Books for Everybody Plan Throughout Country," Tampa Morning Tribune, March 23, 1920, Section Two.

39. "Will Press Books for Everybody Plan Throughout Country," Tampa Morning Tribune, March 23, 1920, Section Two; also, "Books for All," Daily Press, Newport News, Virginia, March 30, 1920, 14.

40. "Will Press Books for Everybody Plan Throughout Country," Tampa Morning Tribune, March 23, 1920, Section Two.

41. "Tampa Library will Supply Ships Books When Exchanged Here," Tampa Morning Tribune, March 10, 1920, 3B.

42. "A.L.A. Library Here to be Moved Away," Daily Press, Newport News, Virginia, October 19, 1919, 11. 